\title{
Knowledge, attitude and practice of undergraduate medical students and interns towards pharmacovigilance
}

\author{
Tushar R. Bagle, Vijay A. Vare*, Rohan C. Hire, Abhaykumar O. Shukla
}

Department of Pharmacology, RGMC and CSMH, Kalwa, Thane, Maharashtra, India

Received: 24 June 2017

Accepted: 03 July 2017

\section{*Correspondence to:}

Dr. Vijay A. Vare,

Email: drvijayvare25@ gmail.com

Copyright: (C) the author(s), publisher and licensee Medip Academy. This is an openaccess article distributed under the terms of the Creative Commons Attribution NonCommercial License, which permits unrestricted noncommercial use, distribution, and reproduction in any medium, provided the original work is properly cited.

\begin{abstract}
Background: Medicines had brought revolution in which diseases are treated and controlled. There are several examples in which using nonstandard medicines had led to death of many patients.

Methods: A cross-sectional questionnaire based study in 200 undergraduate medical students, 150 medical students and 50 interns in a tertiary care hospital. There will be 50 each from II MBBS, III MBBS, IV MBBS and Interns.

Results: The mean age was $23.68+1.64$ years. In the elements of Pharmacovigilance, 5 students feel it is only detection, 4 for assessment, 1 for understanding, 5 for prevention and 142 (II:22, III:41, IV:36, Intern:43) all of the above elements while 43 don't know about the elements of Pharmacovigilance. The factors that discourage from reporting ADR, among this did not know how to report was statistically significant compared to other factors. In students view on problems faced while reporting ADR, among them unawareness of the need to report an ADR and lengthy paper work were statistically significant. (69\%) feel internet is the best reference aid to gather information on ADR to new medicines while $(39.5 \%)$ prefer text books.

Conclusions: The learning of PV should start as early as possible in medical school and should be frequently held to increase the Knowledge, attitude and practice of healthcare professionals regarding ADR's monitoring.
\end{abstract}

Keywords: ADR, Curriculum, Medical students, Pharmacovigilance, Reporting

\section{INTRODUCTION}

Medicines are important due to their capacity to treat and prevent disease and to support public health programs. Medicines also give confidence to the public in the health policies as their countries are linked to confidence in availability of safe and effective medicines. All medicines have some risk of intended and unwanted harm that needs to be monitored. ${ }^{1}$

With respect to mortality Adverse drug reaction (ADRs) has secured among the top 10 leading causes of mortality in some countries. ${ }^{2}$ In some countries an average $10-20 \%$ of medicines fail laboratory tests for quality. Substandard products and counterfeit medicines may cause serious harm to health or exacerbate the conditions being. ${ }^{1}$
A medicine after finishing clinical trials is put in market and legally free for consumption by general population. The safety and efficacy experience of new medication is based on clinical trials. After the clinical trials, the next step is registration and marketing of medicine in the country. ${ }^{3}$ Thus the safety profile is checked only in few individuals in clinical trials and the need for postmarketing monitoring system becomes essential. ${ }^{4}$

World Health Organization (WHO) has explained Pharmacovigilance (PV) as activities related to understanding, prevention, assessment and detection of adverse effects or problem with regards to medicine. ${ }^{2}$ The monitoring of adverse drug reaction was highlighted first time in 1965 at the eighteenth World Health Assembly. ${ }^{1}$ The ultimate benefit is the safe, rational and effective use 
of medicines by patients in a well-organized pharmacovigilance system. ${ }^{3,5}$

According to WHO, PV includes regulation of medicines in National drug policy and public health programmes monitored by 117 countries. ${ }^{3}$ As per Global safety database 2013 , USA ranks $1^{\text {st }}$ with $55 \%$ and India ranks $7^{\text {th }}$ position with $2 \%$ contribution. ${ }^{6}$

Pharmacovigilance Programme of India (PvPI) has ADR Monitoring Centres that collect and follow up ADR reports received from the hospital. ${ }^{7}$ With the advancement the scope of Pharmacovigilance has been widened to include, blood products, medical devices, biological vaccines and even traditional and complementary medicines. ${ }^{1}$ With the advance in Pharmacovigilance in India there is need for the involvement of the undergraduate medical students as they are the physicians of the future. Thus, this study was undertaken to know the undergraduate medical students knowledge, attitude and practice of Pharmcovigilance with the current scenario.

\section{METHODS}

A cross-sectional questionnaire based study in 200 undergraduate medical students, 150 medical students and 50 interns in a tertiary care hospital. There will be 50 students each from II MBBS, III MBBS, IV MBBS and Interns. The objectives of the study were explained to participants and written Informed consent was taken prior to enrollment. Demographic information and Questionnaire was administered and taken back after 2030 minutes. Study duration was from 01 March 2015-31 March 2017. Study site was department of Pharmacology and Therapeutics in a tertiary care hospital and medical college.

Pilot study prior to the current study was conducted where responses of 10 students was assessed. The validity (content and criterion) and reliability (test-retest reliability) of the questionnaire was tested. Internal consistency reliability by Cronbach's alfa coefficient was 0.86 .
Participation in the study was voluntary and students willing to give informed consent were enrolled in study. The demographic profile and study questionnaire were administered and collected after 30-50 minutes. Those students not willing to participate, did not return the questionnaire or returning incompletely filled forms were excluded from the study. Out of 247 questionnaires distributed, 223 were collected and 200 were selected by inclusion and exclusion criteria. Confidentiality of participants and data was maintained throughout the study. The questionnaire was prepared from previous studies and contained questions encompassing the aspects of knowledge, attitude and practice of Pharmacovigilance..$^{8-11}$ The study was done according to principles of Institutional Ethics committee on human experimentation and with the Declaration of Helsinki.

The data was represented in figures, percentages, mean \pm standard deviations. $\mathrm{P}<0.05$ was considered statistically significant. Chi square test will be used to test the association of different variables with socio-demographic data of the participants. ANOVA was used for parametric data. The statistical analysis in the study was done using Graphpad software version 5.0.

\section{RESULTS}

The average age in our study was $23.68 \pm 1.64$ years. There were 124 females and 79 males. Regarding understanding of Pharmacovigilance 25 students feel it is for safe, effective, appropriate and economic use of medicines, 08 feel it is for Therapeutic drug monitoring 42 feels that it is for detection, assessment, understanding and prevention of adverse effects while 104 (II [II MBBS]:22, III [III MBBS]:25, IV [IV MBBS]:26, Intern:33) feel it includes all of the above aspects on understanding. In the functions of Pharmacovigilance, 20 students feel it is mainly used only for detection of ADRs, 19 for measurement of risk and effectiveness of medicine use, 8 for Dissemination of ADR information and education 128 (II:30, III:27 IV:34, Intern:37) all of the above functions. The age, gender and importance of Pharmacovigilance distribution is given in Table 1.

Table 1: Age, gender and class attended and importance of PV distribution among MBBS students.

\begin{tabular}{|llllll|}
\hline Academic year & & II MBBS & III MBBS & IV MBBS & Interns \\
\hline \multirow{2}{*}{ Age } & Mean & 21.76 & 22.5 & 24.96 & 25.51 \\
\hline \multirow{2}{*}{ Gender } & SD & 1.04 & 1.55 & 1.29 & 2.67 \\
\hline \multirow{2}{*}{ Attended class on PV } & Females & 40 & 35 & 22 & 24 \\
\hline \multirow{3}{*}{ Importance } & Males & 10 & 15 & 28 & 26 \\
& Yes & 27 & 32 & 23 & 36 \\
\cline { 2 - 6 } & No & 23 & 18 & 27 & 14 \\
\cline { 2 - 6 } & Very Important & 23 & 27 & 13 & 35 \\
\cline { 2 - 6 } & Important & 24 & 21 & 6 & 14 \\
\cline { 2 - 6 } & Not Important & 3 & 2 & 0 & 1 \\
\cline { 2 - 6 } & Not Important at all & 0 & 0 & & 0 \\
\hline
\end{tabular}


The age was statistically significant $(p<0.0001)$. The II MBBS age was statistically significant to IV MBBS and Interns $(\mathrm{P}=0.001)$ and III MBBS age was statistically significant to IV MBBS and Interns. Interns attended more classes on Pharmacovigilance and was statistically significant $(\mathrm{p}=0.04)$. The students from all year had given equal importance to Pharmacovigilance $(\mathrm{p}=0.174)$.

In the elements of Pharmacovigilance, 5 students feel it is only for Detection, 4 for Assessment, 1 for Understanding, 5 for Prevention and 142 (II:22, III:41, IV:36, Intern:43) feel all of the above elements while 43 don't know about the elements of Pharmacovigilance. With regards to reporting of Pharmacovigilance 57 students feel it includes reporting of drug related problem, 5 feel for Medical devices and vaccines, 5 for Traditional and complementary medicines, 2 for Blood products. 89 All of the above should be reported (II:15, III:19, IV:28, Intern:27), 42 for don't know what Pharmacovigilance reporting includes. Students view on Serious Adverse Event (SAE) is given in Table 2.

Table 2: Students view on serious adverse event.

\begin{tabular}{|llllll|} 
& II & III & IV & Interns & Total \\
\hline & MBBS & & & \\
\hline Results in death & 1 & 2 & 3 & 0 & 6 \\
\hline Is life-threatening & 11 & 7 & 4 & 1 & 23 \\
\hline $\begin{array}{l}\text { Requires } \\
\text { prolongation of } \\
\text { hospitalization or } \\
\text { in patient } \\
\text { hospitalization }\end{array}$ & 9 & 11 & 4 & 3 & 27 \\
\hline $\begin{array}{l}\text { Results in } \\
\text { significant or } \\
\text { persistent } \\
\text { disability/ }\end{array}$ & 0 & 0 & 1 & 1 & 2 \\
incapacity & & & & & \\
\hline $\begin{array}{l}\text { Congenital birth } \\
\text { defect }\end{array}$ & 0 & 0 & 0 & 1 & 1 \\
\hline All of the above & 23 & 26 & 28 & 33 & 110 \\
\hline Don't Know & 6 & 4 & 10 & 11 & 31 \\
\hline
\end{tabular}

The International center of Adverse Drug Reaction monitoring according to 32 students is located in United States of America, 7 feel to be located in France, 7 in Australia, 40 in Sweden and 114 Don't Know (II:31, III:29, IV:31, Intern:23). With regards to Pharmacovigilance program in India 56 students feel it is coordinated by DCGI (Drug Controller General of India), 77 by Indian Pharmacopeia Commission (Ghaziabad), 32 by Director General and 23 feel to be ICMR while 12 students don't know about the coordinator. 48 students feel that National Pharmacovigilance program in India is governed by Medical Council of India, 54 CDSCO under the aegis of Health and Family Welfare, 19 Pharmacy Council of India, 79 (II:25, III:20, IV:22, Intern:12) Don't know.
While matching the ADR reporting system of the respective countries they were matched rightly by 35 students which included, 6 students matched right for Yellow card: UK (United Kingdom), 2 for Blue card for Australia, 26 for ADR-India, while 165 students matched the answers incorrectly. The software used to report ADR 47 feel it is Digiflow, 56 Don't Know about the software while 97 answered it incorrectly. According to 19 students ADR should be reported only when it is serious and life threatening, 24 for severe and cause disability, 15 when causes prolonged hospitalization and 147 (II:29, III:39, IV:38, Intern:41) feel it is reported when all are present. Currently to gather information about ADRs to known medicines, 151 students prefer text books, 63 Journals, 33 Medicine advertisements and product catalogs, 72 Medical representatives, 49 Seminars / conferences and 166 (II:45, III:46, IV:36, Intern:39) refer to Internet.

For importance of reporting ADRs 148 (II:32, III:38, IV:31, Intern:47) feel it is very Important, 48 feel it is important, 2 Slightly Important, 2 Not important and none feel it is not important at all. 124 students feel is it important to report ADRs to identify and detect new ADRs, 153 feel it is important to improve patient safety, 127 feel to identify relatively safe medicine, 105 to measure the incidence of ADRs, 74 feel it is important to share information about ADRs with colleagues.

Table 3: Factors that discourage from reporting ADRs.

\begin{tabular}{|llllll|}
\hline & II & III & IV & Interns & Total \\
\hline & MBBS & & & \\
\hline $\begin{array}{l}\text { Did not know } \\
\text { how to report }\end{array}$ & 37 & 32 & 26 & 17 & 112 \\
\hline $\begin{array}{l}\text { Did not think it to } \\
\text { be important }\end{array}$ & 12 & 6 & 4 & 6 & 28 \\
\hline $\begin{array}{l}\text { Managing patient } \\
\text { was more } \\
\text { important than } \\
\text { reporting ADR }\end{array}$ & 15 & 37 & 38 & 35 & 125 \\
\hline $\begin{array}{l}\text { Lack of access to } \\
\text { ADR Reporting } \\
\text { forms }\end{array}$ & 25 & 27 & 22 & 21 & 93 \\
\hline $\begin{array}{l}\text { Patient } \\
\text { confidentiality }\end{array}$ & 13 & 20 & 10 & 25 & 68 \\
issues & 14 & 14 & 7 & 23 & 56 \\
\hline $\begin{array}{l}\text { Legal liability } \\
\text { issues }\end{array}$ & & & & & \\
\hline
\end{tabular}

The decisive factors that are important while deciding to report an ADR, 119 (II:17, III:29, IV:32, Intern:41) students feel when the ADR is serious, 28 for unusualness of the reaction, 30 for Involvement of a new medicine, 23 when the physician is confidence in diagnosing an ADR. In Table 3 are the factors that discourage from reporting ADR, among this did not know how to report was statistically significant $(\mathrm{p}=0.0004)$ compared to other factors. In Table 4 are the students view on problems faced 
while reporting ADR, among them unawareness of the need to report an ADR and lengthy paper work were statistically significant $(\mathrm{p}<0.0001)$.

Table 4: Students view on problems faced while reporting ADRs.

\begin{tabular}{|c|c|c|c|c|c|}
\hline & II & III & IV & Interns & Total \\
\hline \multicolumn{6}{|c|}{ MBBS } \\
\hline $\begin{array}{l}\text { Lack of information } \\
\text { provided by the } \\
\text { patient }\end{array}$ & 8 & 15 & 19 & 11 & 53 \\
\hline $\begin{array}{l}\text { Don't have enough } \\
\text { time }\end{array}$ & 2 & 9 & 16 & 15 & 42 \\
\hline $\begin{array}{l}\text { Lengthy paper } \\
\text { work }\end{array}$ & 1 & 12 & 12 & 21 & 46 \\
\hline $\begin{array}{l}\text { Unaware of the } \\
\text { need to report an } \\
\text { ADR }\end{array}$ & $\begin{array}{l}3 \\
8\end{array}$ & 12 & 1 & 0 & 51 \\
\hline $\begin{array}{l}\text { Fear of facing legal } \\
\text { problems }\end{array}$ & 1 & 2 & 2 & 3 & 8 \\
\hline
\end{tabular}

According to students, persons that are qualified to report ADR, 59 students feel they are Medical Practitioners, 16 dentists, 3 Nurse, 1 Physiotherapists, 6 Pharmacists, 16 patients and 99 (II:13, III:19, IV:28, Intern:39) All of the above. 170 (85\%) were interested in participating in the Pharmacovigilance ADR reporting system while 140 (70\%) students think ADR reporting as a professional obligation. The scale used for causality assessment 45 students feel it was for World Health OrganizationUppsala Monitoring Centre (WHO-UMC), 9 for Anatomical Therapeutic Chemical (ATC), 7 None of the above scales while 139 (II:43, III:45, IV:35, Intern:16) don't Know. $138(69 \%)$ feel internet is the best reference aid to gather information on ADR to new medicines, 79 Reference text books ,63 Medical journals, 57 Medical / Sales representatives, 51 Drug Information sheets/ leaflets, 20 Information bulletins by Ministry of Health. 29 students know where ADR form is available, 25 know where to submit the filled ADR form while 175 do not know. 36 have seen patient experiencing an adverse drug reaction, 15 have seen adverse drug reaction being reported form being filled.

\section{DISCUSSION}

Pharmacovigilance is an integral and essential part of patient care. Spontaneous reporting of ADR by health care professionals is backbone of pharmacovigilance program. It helps in detection and preventing ADR of medicinal products.

In our study the knowledge questions were answered correctly more by Interns and fourth MBBS less by second year students. Study by Abubakar the mean age of medical students was 24.14 years, $71 \%$ males and $29 \%$ females. $^{12}$ The age and gender distribution in our study was similar to other studies like Kulmi. ${ }^{13}$ Study by Dhananjay had $65 \%$ students that know elements of PV, $87 \%$ that knew about pharmacovigilance. ${ }^{14}$ Study by Vakade had $34.09 \%$ interns that correctly defined Pharmacovigilance, $44.31 \%$ were aware of the purpose of pharmacovigilance. $26.13 \%$ interns were aware of the location of international ADR monitoring center while $51.13 \%$ interns had knowledge about the regulatory body involved in the regulating ADR in India. ${ }^{15}$

Study by Dhananjay had $51 \%$ students that knew IPC, Ghaziabad is the nodal body of pharmacovigilance and $50 \%$ knew UMC, Sweden as the International ADR monitoring centre. ${ }^{14}$ In study by Meher ADR was defined correctly by, $61.67 \%$ of second year students, $80 \%$ of prefinal and $61 \%$ students of final year. $30 \%$ of final, $41 \%$ of prefinal and $22 \%$ of second year student know the definition of pharmacovigilance. $67 \%$ of final year, $55 \%$ of prefinal year, and $56.67 \%$ of $2^{\text {nd }}$ year students knew about IPC, Gaziabad. The practice of PV was same for the students in all year. $38 \%, 44 \%$ and $40 \%$ of final, prefinal and $2^{\text {nd }}$ year students knew the persons that can report ADR. ${ }^{16}$ Similar results were seen in studies by Tabassum and Vora in undergraduate medical students. ${ }^{17,18}$ The knowledge by students in our study was similar to other studies, thus making the need of frequent lectures on Pharmacovigilance.

In our study $70 \%$ students feel ADR reporting as professional obligation while $28 \%$ had legal liability issues that discourage them from writing ADR. Study by Abubakar had $82 \%$ students that agreed on of the important health care workers responsibility is ADR reporting. $52 \%$ worried about a legal aspect of PV while $4 \%$ have reported ADRs; only $8 \%$ had access to the ADRs reporting form. ${ }^{12}$ Study by Dhananjay had $81 \%$ students that had seen ADR but only $31 \%$ knew about ADR reporting form and $20 \%$ have reported ADR. $45 \%$ students think that ADR reporting is a medical professions obligation. ${ }^{14}$ Study by Khan had $75.9 \%$ of medical students that didn't have knowledge about where and how to report ADRs that was a major reason for nonreporting. ${ }^{19}$

A metanalysis conducted by Bhagavathula $55.6 \%$ of the students were unaware of PvPI programme. ${ }^{20} 34.09 \%$ interns were aware about ADR reporting form. The awareness of PV among interns was inadequate. ${ }^{16}$ Systematic review by Bhagavathula was aimed at assessing the Knowledge, Attitude and Practice (KAP) towards PV and ADR reporting in studies conducted in India during January 2011 to July 2015 found major lacunae in KAP towards PV and specially in practice of $\mathrm{PV}$ in India. There is therefore an urgent need for awareness, simplification, and successful implementation of steps to ensure, that practice healthcare professionals PV. ${ }^{20}$

In our study not knowing how to report an ADR was important reason that discourage from reporting ADR. Also, unawareness of how to report an ADR and lengthy 
paperwork are important problems faced while reporting ADR. Medical students had adequate knowledge positive attitude but lacking in practice.

Study by Dhananjay had reported that lack of adequate $\mathrm{KAP}$ is responsible for underreporting of ADR. ${ }^{14}$ In study by Rishi, the causes of underreporting for medical practitioners ADR was busy schedule (22\%), do not know whom to report $(14 \%)$, reporting could show ignorance (5\%), negligence, apathy, general casualness (12\%) toward ADR reporting, and do not want to take responsibility for fear of legal action. ${ }^{21}$

One of the better means of overcoming under-reporting is to increase the KAP of healthcare professionals regarding ADR's monitoring and pharmacovigilance programmes. Similar results were shown by Abubakar and study by Vora. ${ }^{12,18}$

In India Pharmacovigilance still has a long way to go and suffers from underreporting of ADRs, this can delay ADRs reporting. ${ }^{22}$ There is a need for training and educational activities like Continuing Medical Education's for increasing awareness about reporting of ADRs. Importance on adverse event reporting should be emphasized while teaching undergraduate and post graduate students. ${ }^{14,23}$ There is important role of knowledge and motivation in ADR reporting. The monitoring of ADRs should be considered to be an integral part of patient care. According to the Uppsala Monitoring Centre, courses should be taught to undergraduate students on rational use of medications and ADR reporting. ${ }^{19,25}$ Similar results in study by Suveges had revealed that enhancing KAP and increasing awareness of PV can substantially improve ADR reporting. ${ }^{24}$ Study by Arici in which PV training increased the students' knowledge significantly, but long-term impact of the training was limited, thus repeated training of $\mathrm{PV}$ is necessary. ${ }^{26}$ Medical students lack in knowledge and practice but have positive attitude toward ADR reporting. Medical students can provide more efficient health services in their future practices. ${ }^{27}$ To improve ADR monitoring and reporting there is need to integrate pharmacovigilance and medical curriculum. ${ }^{16}$ Educating MBBS students will produce health-care professionals competent in pharmacovigilance. $^{28}$

The learning of PV should start as early as possible in medical school. ${ }^{27}$ The amount of time dedicated to teaching of PV in undergraduate and postgraduate courses in Pharmacology is low. ${ }^{23}$ If all medical schools in India incorporate the ADR reporting skill in their curriculum, definitely future health-care professionals will be competent and confident in reporting the ADR.

\section{ACKNOWLEDGEMENTS}

The authors would like to thank Dean Dr. C. Maitra and Dr. S. Kartikeyan, Prof and Head, P.S.M Department for their support.
Funding: No funding sources

Conflict of interest: None declared

Ethical approval: The study was approved by the Institutional Ethics Committee (RGMC/CSMH/IEC/1/3 dated 27/1/2015)

\section{REFERENCES}

1. World Health Organization. The Safety of Medicines in Public Helath Programmes. Pharmacovigilance an essential tool. World Health Organization. 2006. Available at: http://www.who.int/medicines/areas/quality_safety/sa fety_efficacy/Pharmacovigilance_B.pdf [Accessed 24 March 2017]

2. World Health Organization. Pharmacovigilance: Ensuring the Safe Use of Medicines - WHO Policy Perspectives on Medicines. Available at: http://apps.who.int/medicinedocs/en/d/Js6164e/1.htm 1 [Accessed 23 March 2017]

3. World Health Organization. Pharmacovigilance: ensuring the safe use of medicines. WHO Policy Perspectives on Medicines. 2004;1-8.

4. Indian Pharmacopoeia Commission. Pharmacovigilance Programme of India: Frequently Asked Questions in Pharmacovigilance Programme Of India. Available at: http://www.ipc.gov.in/PvPI1/pv_faq.html [Accessed 13 May 2017]

5. Indian Pharmacopoeia Commission. Pharmacovigilance Programme of India: About PvPI. Available http://www.ipc.gov.in/PvPI1/pv_about.html [Accessed 14 May 2017]

6. Kalaiselvan V. India contribution to WHO-UMC Global Drug safety database for the year 2013. Pharmacovigilance programme of India Newsletter. 2014;8(4):4-5.

7. Indian Pharmacopoeia Commission. Pharmacovigilance Programme of India: ADR monitoring centres. Available at: http://www.ipc.gov.in/PvPI1/pv_amcs.html [Accessed 14 May2017]

8. Radhakrishnan R, Vidyasagar S, Varma DM. An Educational Intervention to assess Knowledge Attitude Practice of pharmacovigilance among Health care professionals in an Indian tertiary care teaching hospital. International Journal of Pharm Tech Research. 2011;3(2):678-92.

9. Rehan HS, Sah RK, Chopra D. Comparison of knowledge, attitude and practices of resident doctors and nurses on adverse drug reaction monitoring and reporting in a tertiary care hospital. Indian $\mathbf{J}$ Pharmacol. 2012;44:699-703.

10. Khan SA, Goyal C, Chandel N, Rafi M. Knowledge, attitudes, and practice of doctors to adverse drug reaction reporting in a teaching hospital in India:An observational study. J Nat Sc Biol Med. 2013;4:191-6.

11. Reddy LV, Pasha SK, Rathinavelu M, Reddy P. Assessment of Knowledge, Attitude and Perception of 
Pharmacovigilance and Adverse Drug Reaction Reporting among the Pharmacy Students in South India. IOSR Journal of Pharmacy and Biological Sciences (IOSR-JPBS). 2014:9(2):34-43.

12. Abubakar AR, Chedi BA, Mohammed KG, Haque M. Perception of Nigerian medical students on adverse drug reaction reporting. J Adv Pharm Technol Res. 2015;6:154-8.

13. Kulmi M, Reddy P, Dhakre S, Shinde M, Goyal C. Knowledge, attitude and practices of pharmacovigilance among the postgraduate and undergraduate medical students in a tertiary care hospital in Central India. Int J Basic Clin Pharmacol. 2017;6:1127-32.

14. Dhananjay K, Esanakula H. A study of assessing knowledge, attitude and practice of pharmacovigilance among medical students of a South Indian teaching hospital. Int J Basic Clin Pharmacol. 2017;6:43-7.

15. Vakade KP, Sangisetti VM, Binayke MV, Abhavathi VN, Nayak BB. An evaluation of knowledge, attitude and practice of pharmacovigilance among interns in a tertiary care teaching hospital of North Maharashtra. Int J Basic Clin Pharmacol. 2016;5:2321-5.

16. Meher BR, Joshua N, Asha B, Mukherji D. A questionnaire based study to assess knowledge, attitude and practice of pharmacovigilance among undergraduate medical students in a Tertiary Care Teaching Hospital of South India. Perspect Clin Res. 2015;6:217-21.

17. Tabassum R, Bhat MY, Farhat S. A descriptive study of knowledge of Pharmacovigilance and adverse drug reactions among second professional undergraduate medical students in a teaching hospital. Int $\mathrm{J}$ Basic Clin Pharmacol. 2015;4:1016-20.

18. Vora MB, Paliwal NP, Doshi VG, Barvaliya MJ, Tripathi CB. Knowledge of adverse drug reactions and pharmacovigilance activity among the undergraduate students of Gujarat. Int J Pharm Sci Res. 2012;3:15115.

19. Khan MU, Ahmad A, Ejaz A, Rizvi SA, Sardar A, Hussain K, et al. Comparison of the knowledge, attitudes, and perception of barriers regarding adverse drug reaction reporting between pharmacy and medical students in Pakistan. J Educ Eval Health Prof. 2015;12:28.

20. Bhagavathula AS, Elnour AA, Jamshed SQ, Shehab A. Health Professionals' Knowledge, Attitudes and Practices about Pharmacovigilance in India: A
Systematic Review and Meta Analysis. Plos One. 2016;1(3):e0152221.

21. Rishi RK, Patel RK, Bhandari A. Under reporting of ADRs by medical practitioners in India- results of pilot study. Adv Pharmacoepidem Drug Saf. 2012;1(3):112-3.

22. Radhika Rani KC, Hemanth GV, Vasundaradevi B, Sadana A, Prameela G. Assessment of Awareness, Knowledge and Methods Of Application Of Pharmacovigilance Among Internees And Postgraduates In A Government Hospital. International Journal of Medical Science and Clinical Inventions. 2015;2(6):1089-96.

23. Tandon VR, Mahajan V, Khajuria V, Gillani Z. Underreporting of adverse drug reactions:A challenge for pharmacovigilance in India. Indian J Pharmacol. 2015;47:65-71.

24. Suveges LG, Gesy KF, Wallace SM, Blackburn JL, Appel WC. Adverse drug reaction reporting part II: evaluation of the Saskatchewan pilot project for a regional reporting program in Canada. Drug Information Journal. 1995;29:581-9.

25. Bagewadi HG, Rekha MS, Sabari AJ. A comparative evaluation of different teaching aids among fourth term medical students to improve the knowledge, attitude and perceptions about pharmacovigilance: An experimental study. International Journal of Pharmacological Research. 2015;5(4):91-7.

26. Arici MA, Gelal A, Demiral Y, Tuncok Y. Short and long-term impact of pharmacovigilance training on the pharmacovigilance knowledge of medical students. Indian J Pharmacol. 2015;47:436-9.

27. Abubakar AR, Haque M. Pharmacovigilance Practice: The Current Challenges and the Gaps in the Medical Students' Curriculum. J App Pharm Sci. 2016;6(05):210-5.

28. Tripathi RK, Jalgaonkar SV, Sarkate PV, Rege NN. Implementation of a module to promote competency in adverse drug reaction reporting in undergraduate medical students. Indian J Pharmacol. 2016;48:S6973.

Cite this article as: Bagle TR, Vare VA, Hire RC, Shukla AO. Knowledge, attitude and practice of undergraduate medical students and interns towards pharmacovigilance. Int J Basic Clin Pharmacol 2017;6:1904-9. 